dar Valley Limestone of Iowa. Journal of Paleontology, 17:417-450.

- 1947. Brachiopoda of the Percha Shale of New Mexico and Arizona. Journal of Paleontology, 21:297-328.

WANG YU, P. COPPER, AND RoNG JiA-YU. 1983. Distribution and morphology of the Devonian brachiopod Punctatrypa. Journal of Paleontology, 57:1067-1089.

Warthin, A. S., AND G. A. CoOper. 1943. Traverse rocks of Thunder Bay region, Michigan. American Association of Petroleum Geologists Bulletin, 27:571-595.
Williams, A., AND A. J. Rowell. 1965. Morphological terms applied to brachiopods, p. H139-H155. In R. C. Moore (ed.), Treatise on Invertebrate Paleontology, Part $\mathrm{H}$, Brachiopoda. Geological Society of America and University of Kansas Press, Lawrence.

MANUSCRIPT RECEIVED 17 OCTOBER 1985

REVISED MANUSCRIPT RECEIVED 17 MARCH 1986

The junior author provided $\$ 100$ in support of this article.

\title{
ANNOUNCEMENT
}

\section{POLICY ON ILLUSTRATIONS FOR THE JOURNAL}

Beginning with the January 1988 issue, the Journal of Paleontology will change to a page size of $81 / 2 \times 11$ inches. Therefore, effective immediately, figures accompanying manuscripts submitted for publication must be at full page size of $18.3 \times 23.3 \mathrm{~cm}$, or at double column width of $18.3 \mathrm{~cm}$, or at single column width of $9.0 \mathrm{~cm}$. All figures must be submitted at publication size and each mounted upon $81 / 2 \times 11$ in. $(21.5 \times 28 \mathrm{~cm})$ white cardboard. Background may be either white or black. Only original prints of half-tone illustrations will be accepted, because those that previously have been screened will not provide acceptable reproduction. Use numbers (not letters) to identify multiple parts of a figure. Half-tones mounted as multiple square or rectangular parts of a figure should be butted together along straight lines with numbers affixed on the lower right-hand corners of the different parts. 